Marketing in Asia Group

Asian Journal of Business Research

Volume 9 Issue 1, 2019

ISSN 2463-4522 e-ISSN 1778-8933

DOI: $10.14707 / a j b r .190056$

\title{
To Retire or not to Retire: Intention towards Concept of Retirement Village in Malaysia
}

\author{
Xin Jean Lim \\ Faculty of Economics and Management, Universiti Putra Malaysia, Selangor, Malaysia \\ Siew Imm Ng \\ Faculty of Economics and Management, Universiti Putra Malaysia, Selangor, Malaysia \\ Norazlyn Kamal Basha \\ Faculty of Economics and Management, Universiti Putra Malaysia, Selangor, Malaysia
}

\begin{abstract}
The aging population has become a global phenomenon, posing as a major societal issue, especially in developing countries. The retirement village concept has emerged as a reliable option to suit the retirement lifestyle of the elderly. The present study aims to explore the perceptions of Malaysians' buying intentions of retirement village units in Malaysia. Utilizing a quantitative approach, a total of 261 usable questionnaires were collected via self-administrated method and subsequently analyzed using PLS-SEM. Perceived risk, communicability, retirement planning, and social sustainability were found significant in influencing retirement village buying intention. The research findings have implications for both developers and academicians when embarking on retirement village project developments in Malaysia.
\end{abstract}

Keywords: Retirement Village, Elderly, Sustainability, Buying Intention, PLS-SEM, Malaysia

Publication Details: Received 22 Aug 2018; Revised 9 Feb 2019; Accepted 10 Apr 2019 


\section{Introduction}

The Malaysian population aged over 65 years old is projected to increase by more than $15 \%$ in 2030 (Department of Statistic, 2016). With the aging population increasing so rapidly, it is imperative to find ways to assist the older population to live their golden years in relatively good health and comfort. A home acts as a symbolic shelter to people as it represents a sense of safety and comfort. In particular, Tinker et al. (2013) stated that a tailored-made housing design, especially for the elderly, will increasingly become indispensable. Boaz et al. (1999) too had suggested that housing aspirations is more entwined with health and care issues as people turn older. Recently, the concept of retirement villages, which focuses on elderly healthcare and lifestyle, has emerged as a desirable housing option. Likewise, Stimson (2002) stated that retirement village has been extensively been accepted as a viable living option for retired life.

As highlighted by Simpson and Cheney (2007), the development of retirement villages has been associated with three social trends; (1) the medicalization of aging; (2) the development of positive-aging institutions; and (3), the improved lifestyle of the contemporary customer society. Some other push factors that encourage retirees to stay in the retirement village includes deteriorating health, weak family ties, loneliness, the death of a spouse, social isolation, and perceived high health risk (Stimson \& McCrea, 2004).

The acceptance and demand for retirement villages are popularized among the aging population around the world in recent decades (Bernard et al., 2012). In Australia, almost $63 \%$ of the elderly was found to prefer living in retirement villages with professional care services (Judd et al., 2010). Similar trends are expected to be seen in developing countries (i.e., Malaysia). According to the Ministry of Women, Family and Community Development, the demands for senior's citizen homes are expected to increase tremendously by the year 2030 (Thestar.com.my, 2017). As pointed by Thestar.com.my (2017), the percentage of elderly who live alone in Malaysia spiked from $5.1 \%$ from year 2004 to $9 \%$ to year 2014, providing a vast opportunity for the development of retirement villages in Malaysia.

The landscape for retirees, especially among the baby boomers and future generations are changing as they see themselves as more than just grandparents who stay home to look after their grandchildren (Grant, 2006). The current and future elderly now look forward to living a more productive life in their retirement years. Thus, it is likely that the retirement village concept would be perceived positively among Malaysians as well. The current provision for health care facilities, old folk's homes and other facilities for elderly and retirees established by the government and private sectors were insufficient to cater for all the needs of the elderly (Kerr, Rosenberg \& Frank, 2012). An exhaustive review of the pertinent literature revealed that there is a dearth of published research that specifically focused on retirement village buying intention in developing countries. Therefore, the current research, with the moderating effects of generation, aims to examine the factors that influence retirement village buying intention in Malaysia. This study is important for policymakers and housing developers in dealing with decisions that relate to housing properties for the elderly. The awareness to provide appropriate retirement homes for the elderly in Malaysia should be of pivotal interest to ensure elderly's quality of life is enhanced. 
The structure of this paper proceeds as follows. In the next section, we introduce the ecological theory of aging (ETA) as the primary theory that supports the research framework and justification for hypotheses development. Next section discusses the research and sample design, followed by statistical results for the current study. Finally, we offer discussion on the results and conclude the paper with implications as well as recommendations for future studies.

\section{Literature Review}

\section{Ecological Theory of Aging (ETA)}

In the field of gerontology, the ecological theory of aging (ETA) is extensively applied in examining issues on person-environment interaction during old ages (Hu et al., 2015). ETA theorizes a significant relationship between the effects of the environment and the well-being of human beings. According to ETA, the competencies of the elderly and the environment, which refer to the surroundings that the elderly live in, need to be matched in a balanced way to establish a sense of wellbeing (Lawton, 1977). Different combinations of competencies and environment will result in different behavioral outcomes, whereby an imbalance between the two can lead to maladaptive behaviors (Iwarsson, 2005; Lawton, 1977). Based on the above discussion, Figure 1 provides a pictorial depiction of this research model for examining retirement village buying intention. It includes seven main components, namely; perceived risk, communicability, retirement planning, social sustainability, economic sustainability, environmental sustainability and buying intention.

\section{Hypotheses Development}

\section{Perceived Risk and Buying Intention}

Sweeney et al. (1999) stated that perceived risk is "defined as consumers' subjective expectations of a loss when buying or utilizing a product". In this study, perceived risk is proposed as one of the determinants that influence Malaysian's retirement village buying intention. The idea of perceived risk was initially utilized by Bauer (1960) in consumer behavior research. Basically, consumers face various degrees of risk in their daily purchases (Kim, Ferrin, \& Rao, 2008; Taylor, 1974) especially in buying "large ticket" items such as real-estate. This is because house buying is one of the most expensive and complex purchases one can make, which requires a high level of involvement for the consumer (Gibler \& Nelson, 2003; Gronhaug, Kleppe \& Haukedal, 1987). In view of that, perceived risk is typically experienced by individuals when evaluating the buying intention of a retirement village unit; that is, the higher the risk, the lower the overall evaluation of retirement village. As suggested by the previous study (Schiffman \& Kanuk, 2004; Laforet, 2007) perceived risk is categorized into five sub-dimensions namely, financial risk, functional risk, physical risk, psychological risk, and social risk. Hence, we suggested that:

H1 There is a negative relationship between perceived risk and retirement village buying intention. 


\section{Communicability and Buying Intention}

Communicability is also suggested as a factor which may impact the elderly's buying intention of a retirement village unit. Morrison et al. (2001) stated that communicability is concerned with the frequency of imitating behavior performed by others, therefore maybe one of the most persuasive factors that could alter individual decision (Burnkrant \& Cousineau, 1975). From consumer perspectives, adopting recommendations from other users is considered less biased, more credible and truthful compared to information provided by marketers (Daugherty \& Hoffman, 2014). Past studies provided evidence of more than $77 \%$ of shoppers were influenced by the recommendation of other's in decision making (Bigne et al., 2010). To be precise, customer decisions are frequently impacted by communicability from people who they trust, especially in a huge buying situation (Lutz \& Reilly, 1974). In the case of a retirement village unit, communicability refers to the reviews and comments shared by existing buyers that is expected to affect a person's opinion. Therefore, communicability is viewed as one of the factors in influencing buying intention of a retirement village, and the hypothesis is formulated as:

H2 There is a positive relationship between communicability and retirement village buying intention.

\section{Retirement Planning and Buying Intention}

Retirement planning is an individual's financial and non-financial preparation for their retirement life (Hanisch, 1995). Lai et al. (2009) found that that lack of preparation for retirement will generally cause some form of disappointment during retirement. Although planning for retirement can be a challenging task, people are advised to do so as earlier as possible to guarantee a higher living standard in their golden years ( $\mathrm{Ng}$ et al., 2011). Just the action of retirement planning can be highly associated with a person's sense of control over their life (Moen et al., 2005). Therefore, individuals with sufficient retirement planning in place will tend to feel high intention towards buying a unit in retirement village during their old age.

H3 There is a positive relationship between retirement planning and retirement village buying intention.

\section{Social Sustainability and Buying Intention}

Sustainable retirement villages offer living options where elderly' social, economic and environmental needs are well-satisfied (Xia et al., 2015). Social sustainability features highlight all the facilities and activities in a retirement village that caters to the needs the elderly's needs. In terms of living space, the elderly look forward to an independent, secure and private living environment, with access to health-related facilities (KPMG, 2009) due to their physical limitations. The elderly also prefers to participate in community's activities actively to retain and expand their social networks during their old age (Taylor et al., 2014; Quine \& Carter, 2006). Stimson and McCrea (2004) found that independent living with complete facilities and support services were the primary factors that influence relocation to a retirement village. Therefore, the village's developers should respond to this criterion when developing and managing retirement villages, and thus, this study posits the following hypothesis: 
H4 There is a positive relationship between social sustainability and retirement village buying intention.

\section{Economic Sustainability and Buying Intention}

Affordability is an imperative concern when considering staying in a retirement village as majority of the elderly experience reduced financial capability during their retirement age (Poterba et al., 2011). Numerous scholars have suggested that low living costs are one of the push factors that influence residents to move into a retirement village (Buys, 2001; Stimson \& McCrea, 2004). Therefore, neglecting the issue of affordability can negatively influence the consumer demand of retirement village, as financial consideration is an important concern for residents in both pre and post-relocation phases (Crisp et al., 2013; Finn et al., 2011; Kennedy \& Coates, 2008). Even though elderly aspired for an eco-friendly living environment, affordability is still a priority for them (Barker et al., 2012; Zuo et al., 2014). Hence, cost is always a significant element when choosing between retirement options. This leads us to the following hypothesis:

H5 There is a positive relationship between economic sustainability and retirement village buying intention.

\section{Environmental Sustainability and Buying Intention}

Sustainability issues are gaining momentum in the construction industry (Xia et al., 2013). The on-going environmental campaigns provoked an increased awareness in implementing sustainable technologies and innovations in developing housing projects (West, 2001). Developers are encouraged to utilize environmentally friendly materials and consider an efficient architecture building design to minimize environmental issues (Smith, 2009). In the same token, retirement village with sustainable construction practices are highly prioritized by stakeholders as it alleviates negative environmental impact as well as improve elderly's health and well-being (Korkmaz et al., 2010; Green Building Council of Australia, 2011). Thus, the village's developers should focus on environmental sustainability issues when delivering a sustainable retirement village (Zuo et al., 2014). With the widespread acceptance of the green building philosophy, sustainable retirement villages should be viewed as a potential prerequisite in altering elderly's buying intention. The following hypothesis is developed:

H6 There is a positive relationship between environmental sustainability and retirement village buying intention.

\section{Moderating Role of Generation}

The generational theory proposed that individuals can be differentiated based on their different age groups (Ting, de Run, 2015; Rotolo \& Wilson, 2004). For example, individuals born in the early 1950' will behave in ways completely different as compared to those born in the 1960'. Generational cohort marketing has become a practical tool for marketers when segmenting their products as an individual born in the same cohort will share similar values (Schewe \& Noble, 2000). Numerous studies revealed that age arises as an important factor towards individual's retirement 
planning (Richardson \& Kilty, 1989; Joo \& Pauwals, 2002). Hence, it is not far to suggest that the perception of retirement living may also differ according to different age groups. Also, research findings reported that younger and older retirees' have different motivations when relocation to retirement village (Stimson \& McCrea, 2004; Bradsher et al., 1992). Specifically, the younger cohort (i.e., Gen-X) appeared to be more open-minded to the concept of retirement village (Crisp et al., 2012). Thereby, the present study suggests that buying intention of retirement village among Gen- $X$ is perceived to be higher compared to baby boomers. In light of above discussion, the hypotheses are developed as:

H7a Generation moderates the relationship between perceived risk and retirement village buying intention, where the negative relationship between perceived risk and buying intention is stronger among Gen-X.

H7b Generation moderates the relationship between communicability and retirement village buying intention, where the positive relationship between communicability and buying intention is stronger among Gen-X.

H7c Generation moderates the relationship between retirement planning and retirement village buying intention, where the positive relationship between retirement planning and buying intention is stronger among Gen-X.

H7d Generation moderates the relationship between social sustainability and retirement village buying intention, where the positive relationship between social sustainability and buying intention is stronger among Gen-X.

H7e Generation moderates the relationship between economic sustainability and retirement village buying intention, where the positive relationship between economic sustainability and buying intention is stronger among Gen-X.

H7f Generation moderates the relationship between environmental sustainability and retirement village buying intention, where the positive relationship between environmental sustainability and buying intention is stronger among Gen-X.

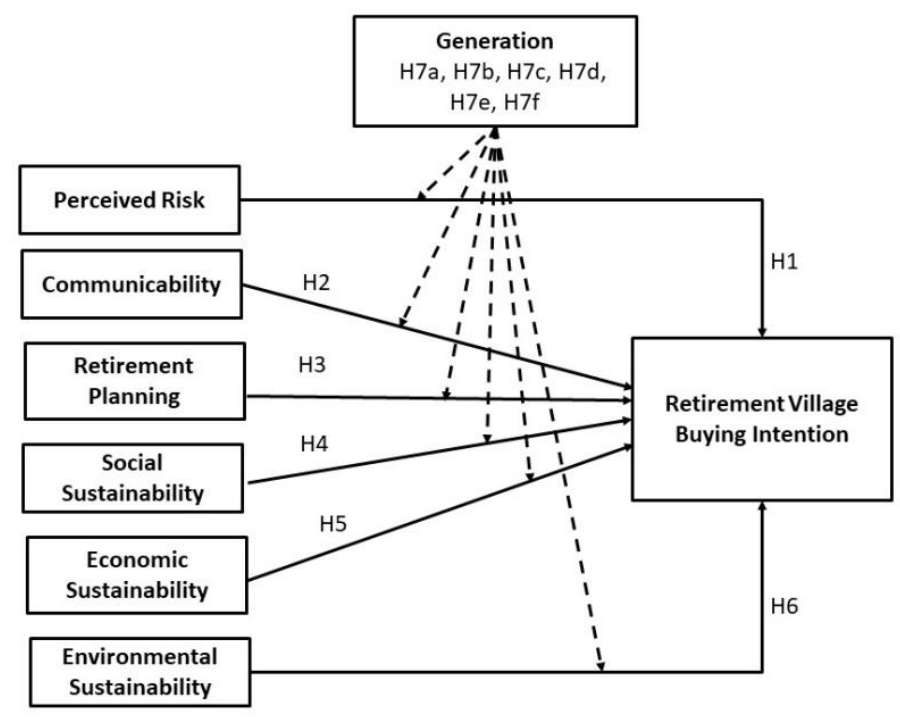

Figure 1: Research Framework 


\section{Research Design}

\section{Sample Design}

Data was collected via a questionnaire through a self-administered survey technique. In quantitative research, a survey design is extensively used by scholars in social sciences, and is the best way to examine the correlation between variables (Zhang, Lu, Gupta, \& Zhao, 2014). This study was participated by 261 (128 male and 133 female) Malaysian in urban areas (see Table 1). Overview of respondent profiling was assessed through SPSS software. Majority of the elderly were married (63.20\%), Malay (41\%) and have 3-4 children (28.4\%). In terms of occupation, $34.10 \%$ of them work in the private sector and $21.80 \%$ of them from the public sector. Retirees compose of $20.60 \%$ of the total respondents.

Table 1: Demographic Characteristics ( $\mathrm{n}=\mathbf{2 6 1})$

\begin{tabular}{|l|c|c|c|}
\hline \multicolumn{1}{|l|}{ Demographic Profile } & Frequency & $\begin{array}{c}\text { Percentage } \\
(\mathbf{\%})\end{array}$ \\
\hline Gender & Male & 128 & $49 \%$ \\
& Female & 133 & $51 \%$ \\
\hline Marital & Married & 165 & 63.20 \\
& Divorced & 18 & 6.90 \\
& Single & 59 & 22.60 \\
Number of & Widowed & 19 & 7.30 \\
\hline Children & None & 65 & 24.90 \\
& $1-2$ & 71 & 27.20 \\
& $3-4$ & 74 & 28.40 \\
& $5-6$ & 34 & 13.00 \\
& $7-8$ & 15 & 5.70 \\
& 8 or more & 2 & 0.80 \\
\hline Ethnicity & Malay & 107 & 41.00 \\
& Chinese & 98 & 37.50 \\
& Indian & 32 & 12.30 \\
& Others & 24 & 9.20 \\
\hline Occupation & Government sector & 57 & 21.80 \\
& Private sector & 89 & 31.40 \\
& Self-employed & 24 & 9.20 \\
& Housewife & 37 & 14.20 \\
& Retired from government sector & 21 & 8.00 \\
& Retired from private sector & 33 & 12.60 \\
\hline & Total & 261 & 100.00 \\
\hline
\end{tabular}

\section{Instrumentation}

All constructs in this study were measured via multiple-item scales and adopted from previous studies as changed to fit the retirement village context. Perceived risk (composed of financial risk, psychological risk, social risk, physical risk, and functional risk) was measured using fifteen items adopted from Featherman and Pavlou (2003). Retirement planning was operationalized using 15 items, adopted from MacFarland et al. (2004); Noone et al. (2010) Petkoska \& Earl (2009); Van Rooij , Lusardi, \& Alessie (2012). Communicability and buying intention was measured 
using two and four items, respectively, adapted from Li \& Buhalis (2006), Morrison et al. (2001) and Ha \& Janda (2012). Three of the sustainability features incorporate of social sustainability, economic sustainability and environmental sustainability were adapted from $\mathrm{Hu}$ et al (2017). All exogenous items were rated on a 5-point Likert scale, where 1 indicated "strongly disagree" and 5 indicated "strongly agree", whereas endogenous variable was measured using 7-point Likert scale.

\section{Findings}

\section{Common Method Bias}

Common method variance issue has gained interest among researchers especially when the data was collected via self-reported questionnaires. Common method variance holds significant attention if data is collected from a single source (Podsakoff et al., 2003). By using Harman's single factor approach, the results revealed that $31.87 \%(<40 \%)$ of the variance was explained by the first factors (Hair et al., 2014), and thus, common method bias was not a serious issue for this study.

\section{Measurement Model}

In this study, confirmatory factor analysis was assessed via Smart PLS 3.2.8 software by examining both the outer model (i.e., validity and reliability) as well as inner model (i.e., hypotheses testing). According to Hair et al. (2017), SEM-PLS was the most appropriate approach for analyzing a complex model as it incorporates both formative and reflective constructs.

\section{Reflective Model}

In reflective measurement model, composite reliability (CR) was used to assess construct internal consistency, with accepted values should greater than 0.70 (Hair et al., 2017). Next, convergent and discriminant validity was assessed. According to Hair et al. (2017), outer loading and average variance extracted (AVE) revealed that convergent validity for the constructs surpassed the recommended thresholds with the value of 0.708 and 0.50 respectively (Hair et al., 2017). As presented in Table 2, all three constructs meet the minimum cut off value for CR, rho_A and AVE. Six items from retirement planning was deleted due to low loading $(<0.40)$. Hulland $(1999)$ stated that items with loading less than 0.40 can be excluded from the reflective model. Identically, Hair et al. (2017) highlighted that items with lower loadings can be considered to be removed from the scale when the deletion will leads to an increase in AVE score.

Table 2: Measurement Model ( $\mathrm{n}=\mathbf{2 6 1})$

\begin{tabular}{|l|l|c|c|c|}
\hline Constructs & Indicators & $\begin{array}{c}\text { Outer } \\
\text { Loading }\end{array}$ & CR & AVE \\
\hline Communicability & COMM1 & 0.915 & 0.935 & 0.878 \\
& COMM2 & 0.958 & & 0.786 \\
\hline Buying Intention & BI1 & 0.883 & 0.936 & \\
& BI2 & 0.910 & & \\
& BI3 & 0.904 & & \\
& BI4 & 0.848 & & \\
\hline
\end{tabular}




\begin{tabular}{|l|l|l|l|l|}
\hline Retirement Planning & RP1 & 0.777 & 0.911 & 0.534 \\
& RP2 & 0.126 & Item Deleted & \\
& RP3 & 0.681 & \\
& RP4 & 0.744 & \\
RP5 & 0.663 & \\
R_RP6 & 0.562 & \\
& R_RP7 & 0.452 & Item Deleted & \\
& R_RP8 & 0.148 & Item Deleted & \\
& R_RP9 & 0.323 & Item Deleted & \\
& RP10 & 0.133 & Item Deleted & \\
& RP11 & 0.202 & Item Deleted & \\
& RP12 & 0.748 & & \\
& RP13 & 0.820 & & \\
& RP14 & 0.729 & & \\
& RP15 & 0.816 & & \\
\hline
\end{tabular}

Note: CR (Composite Reliability), AVE (Average Variance Extracted); RP2, R_RP7, R_RP8, R_RP9, RP10, RP11 are deleted due to low loadings.

Assessment of discriminant validity has become common practice in PLS-SEM studies (Shah \& Goldstein, 2006; Shook et al., 2004). The purpose of examining discriminant validity is to ensure that one construct measure is empirically distinct and symbolize phenomena of interest that do not capture by any others construct in a structural equation model (Hair et al., 2017). Discriminant validity between constructs was assessed using the Heterotrait-Monotrait Ratio of Correlations (HTMT) in the present study. In the HTMT criterion, HTMT value below than HTMT.85 value of 0.85 (Kline, 2011) or HTMT.90 value of 0.90 (Gold, Malhotra, \& Segards, 2001) signifies the construct are different among each other. Therefore, the results as shown in Table 3 indicate sufficient discriminant validity.

Table 3: Discriminant Validity (HTMT Criterion, $\mathbf{n = 2 6 1 \text { ) }}$

\begin{tabular}{|l|c|c|c|}
\hline & Buying Intention & Communicability & $\begin{array}{l}\text { Retirement } \\
\text { Planning }\end{array}$ \\
\hline Buying Intention & & & \\
\hline Communicability & 0.611 & & \\
\hline $\begin{array}{l}\text { Retirement } \\
\text { Planning }\end{array}$ & 0.547 & 0.522 & \\
\hline
\end{tabular}

\section{Formative Model}

Formative measurement model for this study is represented by three components of sustainability features (i.e., social, environmental and economic sustainability). Assessment of redundancy analysis with global item as recommended by Cheah et al. (2018) shows that the path coefficient with global items for three of the constructs values is at $0.752,0.749$ and $0.882(>0.70)$, indicating a sufficient level of convergent validity (Sarstedt, Wilczynski \& Melewar, 2013). Next, variance inflation factor (VIF) values were found below 5 which signify there were no multicollinearity issues for this data set (Hair et al., 2017). Lastly, the significance of formative indicators was assessed via outer weight. Table 4 shows that all the indicators for economic sustainability was significant $(\mathrm{p}<0.05)$. On the other hand, some of the indicators for 
environmental and social sustainability were not significant (p-value > 0.05); however, all these indicators still be retained on the basis of content validity (Hair et al., 2017).

Table 4: Formative Measurement Model $(n=261)$

\begin{tabular}{|c|c|c|c|c|c|c|}
\hline Constructs & Items & $\begin{array}{l}\text { Convergent } \\
\text { Validity } \\
\text { (with the } \\
\text { global item) }\end{array}$ & $\begin{array}{l}\text { Outer } \\
\text { Weight }\end{array}$ & VIF & t-value & p-value \\
\hline \multirow{3}{*}{$\begin{array}{l}\text { Economic } \\
\text { Sustainability }\end{array}$} & ECN1 & \multirow[t]{3}{*}{0.752} & 0.713 & 1.575 & 6.746 ** & 0.000 \\
\hline & ECN2 & & 0.223 & 1.967 & $2.445 * *$ & 0.007 \\
\hline & ECN3 & & 0.206 & 2.051 & $1.737 * *$ & 0.042 \\
\hline \multirow{6}{*}{$\begin{array}{l}\text { Environmental } \\
\text { Sustainability }\end{array}$} & ENV1 & \multirow[t]{6}{*}{0.749} & -0.034 & 2.915 & 0.249 & 0.402 \\
\hline & ENV2 & & 0.137 & 3.955 & 1.014 & 0.156 \\
\hline & ENV3 & & 0.021 & 2.115 & 0.226 & 0.411 \\
\hline & ENV4 & & 0.406 & 1.759 & $4.476 * *$ & 0.000 \\
\hline & ENV5 & & 0.174 & 1.506 & 1.986 & 0.024 \\
\hline & ENV6 & & 0.520 & 1.791 & $5.553 * *$ & 0.000 \\
\hline \multirow{30}{*}{$\begin{array}{l}\text { Social } \\
\text { Sustainability }\end{array}$} & SS1 & \multirow[t]{30}{*}{0.882} & -0.047 & 3.313 & 0.530 & 0.298 \\
\hline & SS2 & & -0.015 & 2.789 & 0.184 & 0.427 \\
\hline & SS3 & & 0.063 & 3.442 & 0.733 & 0.232 \\
\hline & SS4 & & -0.054 & 1.999 & 1.033 & 0.151 \\
\hline & SS5 & & 0.053 & 3.725 & 0.560 & 0.288 \\
\hline & SS6 & & -0.157 & 3.952 & 1.577 & 0.058 \\
\hline & SS7 & & 0.021 & 2.882 & 0.249 & 0.402 \\
\hline & SS8 & & -0.033 & 3.423 & 0.371 & 0.356 \\
\hline & SS9 & & 0.107 & 3.134 & 1.215 & 0.113 \\
\hline & SS10 & & 0.181 & 4.114 & $1.981 *$ & 0.024 \\
\hline & SS11 & & 0.074 & 4.398 & 0.690 & 0.245 \\
\hline & SS12 & & 0.116 & 4.555 & 1.253 & 0.105 \\
\hline & SS13 & & 0.018 & 3.388 & 0.222 & 0.412 \\
\hline & SS14 & & 0.135 & 3.116 & $1.751 *$ & 0.040 \\
\hline & SS15 & & -0.036 & 3.795 & 0.310 & 0.378 \\
\hline & SS16 & & 0.072 & 3.374 & 0.952 & 0.171 \\
\hline & SS17 & & 0.218 & 3.251 & $2.660 * *$ & 0.004 \\
\hline & SS18 & & 0.108 & 4.261 & 1.173 & 0.121 \\
\hline & SS19 & & -0.054 & 1.818 & 1.089 & 0.138 \\
\hline & SS20 & & 0.118 & 3.649 & 1.361 & 0.087 \\
\hline & SS21 & & 0.196 & 4.018 & $2.051^{*}$ & 0.020 \\
\hline & SS22 & & 0.029 & 3.456 & 0.327 & 0.372 \\
\hline & SS23 & & 0.122 & 2.285 & $1.883^{*}$ & 0.030 \\
\hline & SS24 & & -0.003 & 4.251 & 0.028 & 0.489 \\
\hline & SS25 & & -0.121 & 4.634 & 1.143 & 0.127 \\
\hline & SS26 & & 0.065 & 1.818 & 1.002 & 0.158 \\
\hline & SS27 & & 0.185 & 2.750 & $2.395 * *$ & 0.008 \\
\hline & SS28 & & -0.081 & 2.973 & 0.925 & 0.178 \\
\hline & SS29 & & 0.158 & 3.883 & $1.862 *$ & 0.032 \\
\hline & SS30 & & 0.181 & 3.285 & 1.582 & 0.057 \\
\hline
\end{tabular}

Note: $* * \mathrm{p}<0.01,{ }^{*} \mathrm{p}<0.05 ; \mathrm{VIF}<5$ 


\section{Higher Order Construct (Perceived Risk)}

In this study, perceived risk represents reflective-formative higher order components (HOCs) that constitute five lower-order components (LOCs) (i.e., financial risk, psychological risk, social risk, physical risk, and functional risk). Repeated indicator approach is used to obtain the latent variables scores (LVS) for the LOCs in the first stage (Hair et al., 2016). In the second stage, LOCs serve as the manifest variable in the HOC measurement variable (Hair et al., 2016).

Convergent validity of 0.789 (correlations between LOCs) greater than the ideal magnitude of 0.70 (Hair et al., 2016) indicates that all dimension for perceived risk was correlated positively. Collinearity issue was checked using variance inflation factor (VIF) as shown in Table 5. All the LOCs constructs are distinct from each other's with VIF scores less than 3.33 (Diamantopoulous \& Siguaw, 2006). Assessing of significance test exhibited that, functional risk is the only dimension significant ( $t$ value $=2.335$; $p$-value $=0.01$ ). Although the remaining dimensions (i.e., financial risk, psychological risk, social risk, and physical risk) were insignificant, these subdimensions were retained as priori research and theory support for the relevance of these dimension in capturing the concept of perceived risk (Bauer, 1960).

Table 5: Second Order Constructs $(n=261)$

\begin{tabular}{|l|c|c|c|l|c|}
\hline $\begin{array}{l}\text { Sub-Dimension or } \\
\text { LOCs }\end{array}$ & $\begin{array}{l}\text { Convergent Validity } \\
\text { (Global item) }\end{array}$ & Weight & VIF & t-value & p-value \\
\hline Financial Risk & 0.823 & 0.104 & 2.822 & 1.372 & 0.085 \\
\hline Psychological Risk & & 0.184 & 3.179 & $1.922 *$ & 0.028 \\
\hline Social Risk & & -0.018 & 1.746 & 0.269 & 0.394 \\
\hline Physical Risk & & 0.157 & 3.205 & $1.858 *$ & 0.032 \\
\hline Functional Risk & & 0.667 & 2.468 & $8.999 * *$ & 0.000 \\
\hline
\end{tabular}

Note: $* * \mathrm{p}<0.01 ;$ LOC (Low Order Constructs)

\section{Descriptive Statistics}

Table 6 exhibited that the mean score for all the latent variables are ranged between 2.308 to 4.448 whereas the standard deviation ranges from 0.503 to 1.175 within a five-point Likert scale. Among that, social sustainability scored the highest mean (4.448) whereas functional risk showed the lowest mean (2.308). The dispersion values as reported by standard deviation demonstrated that communicability showed the highest value (1.175) however social sustainability represent the lowest value (0.503). Additionally, buying intention exhibited a high mean score (5.074) and a moderate standard deviation (1.369) on a seven-point Likert scale. Table 6 summarizes the result for descriptive analysis.

Table 6: Descriptive Analysis (n=261)

\begin{tabular}{|l|l|c|c|c|}
\hline No & Construct & No of Items & Mean & $\begin{array}{c}\text { Std. } \\
\text { Deviation }\end{array}$ \\
\hline 1 & Perceived Risk- (Financial Risk) $*$ & 3 & 2.457 & 0.893 \\
\hline 2 & Perceived Risk- (Psychological Risk) $*$ & 4 & 2.514 & 0.852 \\
\hline 3 & Perceived Risk- (Social Risk) * & 2 & 2.345 & 0.969 \\
\hline 4 & Perceived Risk- (Physical Risk) & 3 & 2.314 & 0.815 \\
\hline 5 & Perceived Risk- (Functional Risk) * & 3 & 2.308 & 0.855 \\
\hline 6 & Communicability* & 2 & 2.889 & 1.175 \\
\hline
\end{tabular}




\begin{tabular}{|l|l|c|c|c|}
\hline 7 & Retirement Planning* & 9 & 3.799 & 0.735 \\
\hline 8 & Economic Sustainability* & 3 & 4.342 & 0.614 \\
\hline 9 & Environmental Sustainability* & 6 & 4.192 & 0.650 \\
\hline 10 & Social Sustainability* & 30 & 4.448 & 0.503 \\
\hline 11 & Buying Intention** & 4 & 5.074 & 1.369 \\
\hline
\end{tabular}

Note: $* 5$ points Likert scale, $* * 7$ point Likert scale

\section{Structural Model}

Prior to the analysis, the potential existence of multicollinearity issues between the variables was tested using a variance inflation factor (VIF) test, which results indicate that all the variables have VIF values of between 1.266 and 1.808. According to Diamantopoulos \& Siguaw (2006) VIF value of less than 3.33 is apart with collinearity issues.

Table 7: Collinearity Result ( $\mathrm{n}=\mathbf{2 6 1})$

\begin{tabular}{|l|c|}
\hline Construct & Convergent Validity (Global item) \\
\hline Communicability & 1.475 \\
\hline Economic Sustainability & 1.518 \\
\hline Environmental Sustainability & 1.266 \\
\hline Perceived Risk & 1.369 \\
\hline Retirement Planning & 1.808 \\
\hline Social Sustainability & 1.589 \\
\hline
\end{tabular}

The coefficient of determination $\left(\mathrm{R}^{2}\right)$ indicates the amount of variance explained by the exogenous variables (Barclay, Higgins \& Thompson, 1995). All six variables together explained $54.8 \%$ of the variance. By using a bootstrapping re-sampling technique with 500, the path coefficient, $\mathrm{p}$-value and t-value revealed for the hypothesized relationships. As clear from Table 8 , all four factors namely perceived risk $(\beta=-0.404, p=0.000)$, communicability $(\beta=0.244, p=0.000)$, retirement planning $(\beta=0.1444, p=0.015)$ and social sustainability $(\beta=0.43, p=0.006)$ had significantly influence on retirement village buying intention. On the other hand, the relationship between economic sustainability $(\beta=0.023, p=0.015)$ and environmental sustainability $(\beta=0.021, p=0.357)$ on buying intention is insignificant.

Table 8: Path Coefficient ( $n=261)$

\begin{tabular}{|l|l|l|l|l|l|l|}
\hline Path & $\begin{array}{l}\text { Direct } \\
\text { Effect }(\boldsymbol{\beta})\end{array}$ & Std Error & t-value & $\mathbf{p}$-value & $\boldsymbol{f}^{2}$ & Decision \\
\hline H1) PR -> BI & -0.404 & 0.057 & $7.083^{* *}$ & 0.000 & 0.264 & Supported \\
\hline H2) COMM -> BI & 0.244 & 0.058 & $4.205^{* *}$ & 0.000 & 0.089 & Supported \\
\hline H3) RP -> BI & 0.144 & 0.067 & $2.167 * *$ & 0.015 & 0.026 & Supported \\
\hline H4) SS -> BI & 0.143 & 0.057 & $2.503^{* *}$ & 0.006 & 0.028 & Supported \\
\hline H5) ECN -> BI & 0.023 & 0.051 & 0.418 & 0.338 & 0.001 & $\begin{array}{l}\text { Not } \\
\text { Supported }\end{array}$ \\
\hline H6) ENV -> BI & 0.021 & 0.058 & 0.367 & 0.357 & 0.001 & $\begin{array}{l}\text { Not } \\
\text { Supported }\end{array}$ \\
\hline
\end{tabular}

Note: $* * p<0.01$; PR (Perceived Risk), COMM (Communicability), RP (Retirement Planning), SS (Social Sustainability), ECN (Economic Sustainability), ENV (Environmental Sustainability), BI (Buying Intention) 
In the same vein, to measure the magnitude of the effect size $\left(f^{2}\right)$ we adopted Cohen's (1988) rule of thumb which $0.02,0.15$, and 0.35 , representing small, medium, and large effects respectively. The $f^{2}$ score in Table 8 indicated that perceived risk $(0.264)$ has a medium effect size on buying intention. However, there are three constructs demonstrated a small effect size on buying intention which comprises of communicability (0.089), retirement planning (0.026) and social sustainability (0.028). Conversely, both economic (0.001) and environmental sustainability (0.001) showed no effect on buying intention.

The last step of the structural model was evaluating on the predictive validity of the model via blindfolding procedure. Followed Hair et al. (2016), the study stated that exogenous variables have predictive relevance for the endogenous variable if $Q^{2}>0$. Similarly, the $\mathrm{Q}^{2}$ of buying intention equivalent to 0.405 signifies that this model shows a good predictive relevance.

\section{Moderating Effect}

The initial $\mathrm{R}^{2}(=0.548$ ) for the structural model was compared with the model with the inclusion of generation as the moderator. The new $\mathrm{R}^{2}(=0.570)$ with an increase of 0.022 shows that a generation raised a small explanatory power of $2.20 \%$ (Cohen, 1988) as compare to the original model.

Table 9 shows moderation analysis results with generation as the moderator. It can be seen that the effect of economic sustainability $(\beta=0.238, \mathrm{p}<0.05)$ and environmental sustainability $(\beta=-0.141, \mathrm{p}<0.05)$ on retirement village buying intention is moderated by generation. This relationship is strong in the case of Gen-X respondents. Hence hypothesis $\mathrm{H7e}$ and $\mathrm{H} 7 \mathrm{f}$ are supported. However, all other hypotheses are not supported by generation as a moderator.

Table 9: Moderating Effect of Generation $(n=261)$

\begin{tabular}{|l|l|c|c|c|c|l|}
\hline Path & Relationship & Std Beta & Std Error & t-value & p-value & Decision \\
\hline H7a & PR*GEN -> BI & -0.051 & 0.114 & 0.449 & 0.327 & $\begin{array}{l}\text { Not } \\
\text { Supported }\end{array}$ \\
\hline H7b & COMM*GEN -> BI & -0.114 & 0.108 & 1.057 & 0.146 & $\begin{array}{l}\text { Not } \\
\text { Supported }\end{array}$ \\
\hline H7c & RP*GEN -> BI & 0.249 & 0.157 & 1.589 & 0.056 & $\begin{array}{l}\text { Not } \\
\text { Supported }\end{array}$ \\
\hline H7d & SS*GEN -> BI & -0.107 & 0.151 & 0.709 & 0.239 & $\begin{array}{l}\text { Not } \\
\text { Supported }\end{array}$ \\
\hline H7e & ECN*GEN - B BI & 0.238 & 0.124 & $1.925^{*}$ & 0.027 & Supported \\
\hline H7f & ENV*GEN - B B & -0.141 & 0.068 & $2.070^{*}$ & 0.019 & Supported \\
\hline
\end{tabular}

Note: $* *$ p $<0.05$; PR (Perceived Risk), COMM (Communicability), RP(Retirement Planning), SS (Social Sustainability), ECN (Economic Sustainability), ENV (Environmental Sustainability), BI (Buying Intention), GEN(Generation)

The significant moderating relationship was further explained by drawing the interaction plot (Dawson, 2014). As can see in both Figure 3 and4, the dotted line labeled for Gen-X has a steeper slope when compared to baby boomers. This phenomenon demonstrated that the relationship between environmental sustainability and retirement village buying intention as well as the relationship between economic sustainability and retirement village buying intention were stronger among Gen-X. Thus, our hypotheses $\mathrm{H} 7 \mathrm{e}$ and $\mathrm{H} 7 \mathrm{f}$ are supported. 


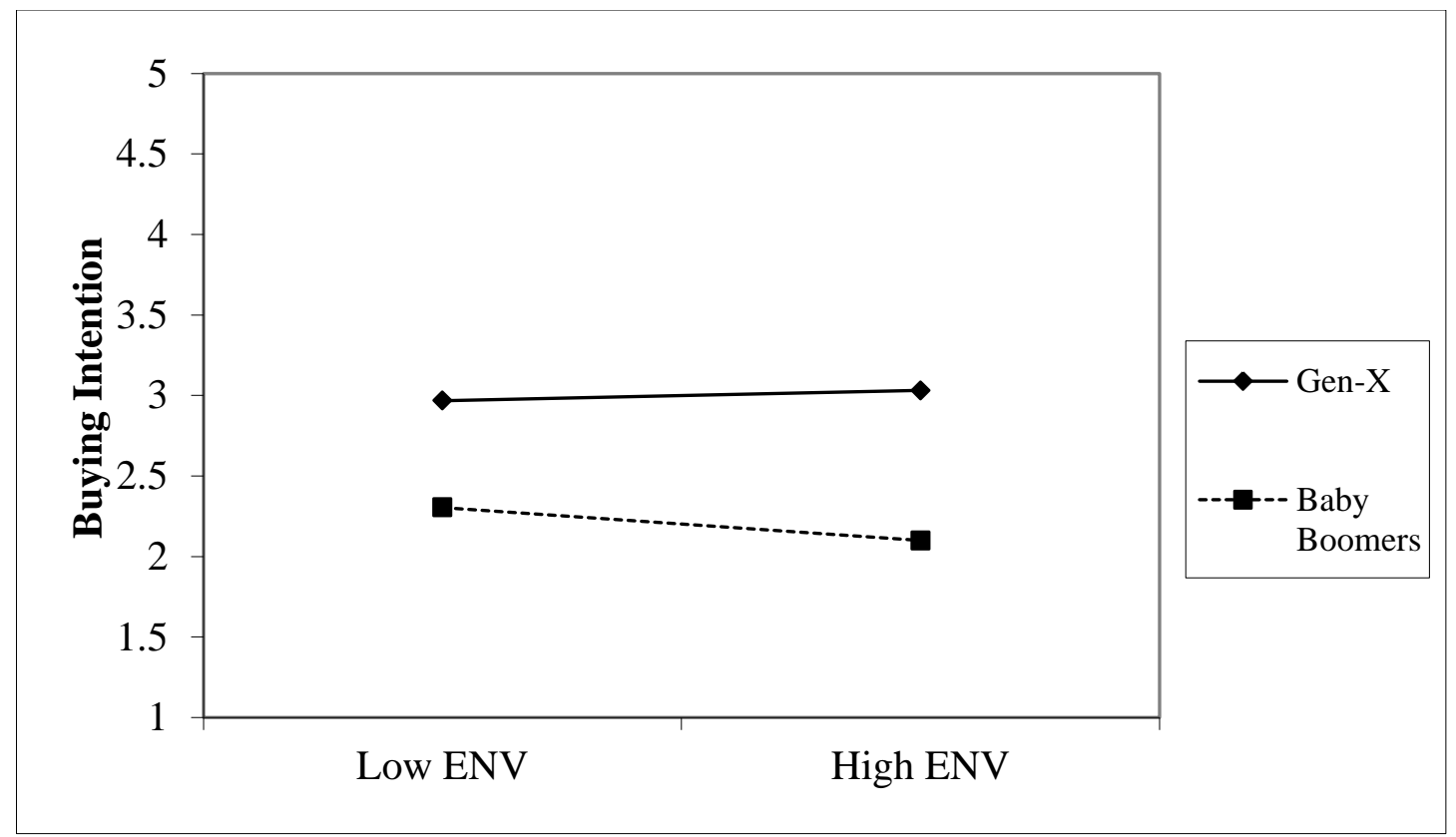

Figure 3: Interaction plot of Environmental Sustainability* Generation

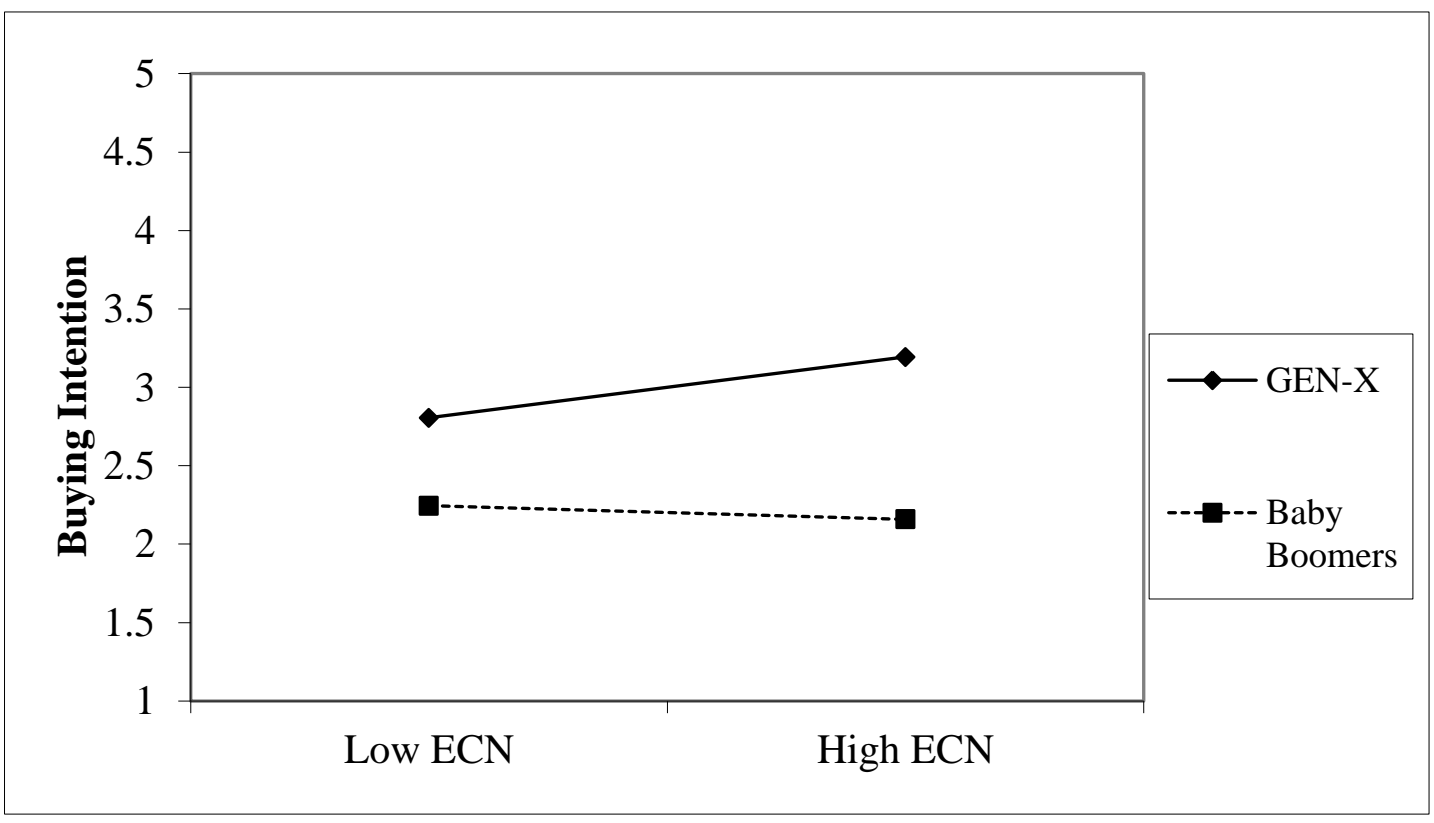

Figure 4: Interaction plot of Economic Sustainability* Generation 


\section{Discussion}

Firstly, there is a significant effect of perceived risk on buying intention. This parallels with previous work which provides robust arguments regarding a direct relationship between perceived risk and buying behavior (Kataria et al., 2016; Gefen, 2002; Thorelli et al., 1989). This finding was similar in retirement village context as this housing option is still a novel idea and may take some time to be accepted among Malaysians. In other words, majority of the respondents are risk-averse when making buying decisions on retirement village. Therefore, developers with an in-depth understanding of the different types of risks experienced by potential retirement unit buyers could alter their value proposition accordingly and implement strategies to enhance the buyer's confidence. In particular, property developers are advised to provide detailed information to reduce buyer's financial, functional and physical risk. Meanwhile, social and psychological risk can be decreased through sharing of living experience by existing residents.

The study also found that communicability positively influenced the intention to buy a unit of retirement village. Today, with the increasing popularity of online social networks such as Facebook and Twitter, online reviews have become one of the most persuasive tools that will impact consumer's evaluation (Fu et al., 2011). Undeniably, online reviews were found to alter consumer behaviors (Goldenberg, Libai \& Muller, 2001; Vermeulen \& Seegers, 2009). Consequently, village developers should take great effort in building a good reputation and persuasive review when marketing the idea of retirement village among Malaysian.

Next, path coefficient results indicated that retirement planning has a significant positive relationship on retirement village buying intention, which suggested that strategic retirement planning will increase the likelihood of buying a retirement village unit. Planning and saving in advance of retirement will assist the elderly to enjoy a comfortable living during their old ages (Kimiyaghalam et al., 2017).

In term of sustainability features, social sustainability has shown a positive relationship with retirement village buying intention. This suggests that a retirement village that comprises of ergonomic consideration will positively influence Malaysian buying intention. Croucher et al. (2006) asserted that the elderly highly value independent and secure living environments, as well as companionship among the community. Therefore, the village's developers must carefully consider social sustainable practices that are specially tailored to the elderly when managing and planning retirement village's facilities.

Meanwhile, contrary to Xia et al. (2015) and Zuo et al. (2014), the study found a nonsignificant relationship between environmental and economic sustainability with buying intention of retirement village. This may be explained by Papargyropoulou et al.'s (2012) study, which suggested that awareness towards environmental issues in Malaysia is relatively low compared to other developed countries. To add to that, the concept of sustainable development in the Malaysian real-estate industry is still at infancy stage (Hassan et al., 2011), hence this criterion was not fully highlighted among the buyers as well as developers (Hassan et al., 2011). 
In terms of economic sustainability, affordability is less of a concern for respondents in this study compared living in a secure environment. This can be explained by the study's scope of the urban respondents with the majority belonging to medium and high-income group. Similarly, research by Crisp at al., (2013) found that higher education levels and greater employment opportunities of urban buyers might show a less constrained financial concern when making a housing decision, as compared to others group of consumers.

Lastly, the moderating effect of generation was found significant between economic sustainability-intention and environmental sustainability-intention relationship. This result was consistent with an extant study which reported that generational cohorts influence consumer's values, preferences, and shopping behavior (Parment, 2011). The findings indicated that generation moderates the relationship between both economic and environmental sustainability features in retirement village buying intention where these relationships are strengthen among Gen-X. This provides a useful insight for the village's developers by uncovering the differences when promoting the concept of retirement village in Malaysia. The significant effect of perceived risk, communicability, retirement planning as well as social sustainability on retirement village buying intention were seen to be identical among both generation (i.e., Gen-X and Baby Boomers). However, both features of economic and environmental sustainability should be prominent when targeting on Gen-X.

\section{Implications and Future Studies}

The current study provides few theoretical and managerial implications. From the theoretical perspective, the current study provides a new theoretical insight in the context of retirement village by using quantitative approach that was lacking in prior studies. Additionally, the present study also verified the applicability of ecological theory of aging (ETA) in explaining the determinants that influence retirement village buying intention in Malaysia.

From the managerial perspective, this study provides interesting insights for property developers to develop and promote retirement village developments in Malaysia. The study's findings show that perceived risk, communicability, retirement planning, and social sustainability are the significant factors that alter Malaysian's buying intention towards a retirement village unit. Hence, developers should highlight these features when developing and promoting their village project in order to gain more acceptances from the buyers. Also, generation cohort may also be used to segment the target market when devising a marketing strategy. In short, the development of retirement villages should be responsive to the perception of Malaysian consumers in order to enhance the quality of retirement life among the elderly in Malaysia.

This study has several limitations. First, the findings of this study merely captured the differences between two generation cohort (i.e., baby boomers and Gen-X). Future studies are suggested to explore other age cohorts as suggested by Ting et al. (2017). In particular, the Malaysian cohorts can be divided into five different groups; for instance, Strivers (those who born during the early 1960s to the late 1970s) were found to focus more on stability and a comfort lifestyle, while Reformers (those who born between 1940s-1960s) struggled to live for a better life, thus, it will be 
interesting to understand their perception toward the concept of retirement village. It is also worth mentioning that this research only examines the elderly's buying intention. Follow-up studies are needed to verify the validity of the model tested in their actual behavior. Furthermore, future studies may delve into subsequent residents' living experience and satisfaction in the retirement villages to provide more useful insights.

\section{Acknowledgment}

This research was supported by Grant Universiti Putra Malaysia (GUPM) (GPIPS/2018/9604600).

\section{References}

Barclay, D., Higgins, C., \& Thompson, R., (1995), The partial least squares (pls) approach to casual modeling: Personal computer adoption ans use as an illustration, Technology Studies, vol. 2, no. 2, pp. 285-309.

Barker, J., Xia, B., Zuo, J., \& Zillante, G., (2012), Sustainable retirement living: what matters, Australasian Journal of Construction Economics and Building-Conference Series, vol. 1, no. 1, pp. 1-8.

Bauer, R. A., (1960), Consumer behavior as risk taking, Proceedings of the 43rd National Conference of the American Marketing Assocation.

Bernard, M., Liddle, J., Bartlam, B., Scharf, T., \& Sim, J., (2012), Then and now: evolving community in the context of a retirement village, Ageing \& Society, vol. 32 no. 1, pp. 103-129.

Bigné, E., Sanz, S., Ruiz, C., \& Aldás, J., (2010), Why some Internet users don't buy air tickets online, Information and Communication Technologies In Tourism, pp. 209221.

Bradsher, J. E., Longino Jr, C. F., Jackson, D. J., \& Zimmerman, R. S., (1992), Health and geographic mobility among the recently widowed, Journal of Gerontology, vol. 47, no.5, pp.261-268.

Burnkrant, R. E., \& Cousineau, A., (1975), Informational and normative social influence in buyer behavior, Journal of Consumer Research, vol. 2, no. 3, pp. 206-215.

Buys, L. R., (2001), Life in a retirement village: implications for contact with community and village friends, Gerontology, vol. 47, no.1, pp. 55-59.

Chaudhuri, A., (2000), A macro analysis of the relationship of product involvement and information search: The role of risk, Journal of Marketing Theory and Practice, vol. 8, no.1, pp.1-15.

Cheah, J. H., Sarstedt, M., Ringle, C. M., Ramayah, T., \& Ting, H., (2018b), Convergent validity assessment of formatively measured constructs in PLS-SEM: On using single-item versus multi-item measures in redundancy analyses, International Journal of Contemporary Hospitality Management, vol.30, no.11, pp. 3192-3210.

Cheah, J. H., Ting, H., Ramayah, T., Memon, M. A., Cham, T. H., \& Ciavolino, E., (2018a), A comparison of five reflective-formative estimation approaches: Reconsideration and recommendations for tourism research, Quality \& Quantity, pp. 1-38.

Cohen, J., (1988), Statistical power analysis for the behavioral sciences, Lawrence Erlbaum Associates.

Crisp, D. A., Windsor, T. D., Butterworth, P., \& Anstey, K. J., (2013), What are older adults seeking? Factors encouraging or discouraging retirement village living, Australasian Journal on Ageing, vol. 32, no. 3, pp. 163-170.

Croucher, K., Hicks, L., \& Jackson, K., (2006), Housing with care for later life: A literature review, Joseph Rowntree Foundation. 
Daugherty, T., \& Hoffman, E., (2014), eWOM and the importance of capturing consumer attention within social media, Journal of Marketing Communications, vol. 20, no. 12, pp. 82-102.

Dawson, J. F., (2014), Moderation in management research: What, why, when, and how, Journal of Business and Psychology, vol. 29, no. 1, pp.1-19.

Department of Statistics Malaysia, (2016), "Current Population Estimates, Malaysia, 20142016", Retrieved from https://www.dosm.gov.my/v1/index.php?r=column/pdfPrev\& id=OWlxdEVoYlJCSOhUZzJyRUcvZEYxZz09

Diamantopoulos, A., \& Siguaw, J. A., (2006), Formative versus reflective indicators in organizational measure development: A comparison and empirical illustration, British Journal of Management, vol. 17, no. 4, pp. 263-282.

Hair, J. F., Sarstedt, M., Hopkins, L., \& G. Kuppelwieser, V., (2014), Partial least squares structural equation modeling (PLS-SEM): An emerging tool in business research, European Business Review, vol. 26, no.2, pp.106-121.

Featherman, M. S., \& Pavlou, P. A., (2003), Predicting e-services adoption: a perceived risk facets perspective, International Journal of Human-Computer Studies, vol. 59, no. 4, pp. 451-474.

Finn, J., Mukhtar, V. Y., Kennedy, D. J., Kendig, H., Bohle, P., \& Rawlings-Way, O., (2011), Financial planning for retirement village living: A qualitative exploration, Journal of Housing for the Elderly, vol. 25, no. 2, pp. 217-242.

Fu, X., Bin, Z., Xie, Q., Liuli, X., \& Yu, C., (2011), Impact of quantity and timeliness of EWOM information on consumer's online purchase intention under $\mathrm{C} 2 \mathrm{C}$ environment, Asian Journal of Business Research, vol. 1, no. 2, pp. 37-52.

Gefen, D., (2002), Reflections on the dimensions of trust and trustworthiness among online consumers, ACM SIGMIS Database, vol. 33, no. 3, pp. 38-53.

Gibler, K., \& Nelson, S., (2003), Consumer behavior applications to real estate education, Journal of Real Estate Practice and Education, vol. 6, no. 1, pp. 63-83.

Gold, A. H., Malhotra, A., \& Segars, A. H., (2001), Knowledge management: An organizational capabilities perspective, Journal of Management Information Systems, vol. 18, no. 1, pp.185-214.

Goldenberg, J., Libai, B., \& Muller, E., (2001), Talk of the network: A complex systems look at the underlying process of word-of-mouth, Marketing Letters, vol.12, no. 3, pp. 211-223.

Grant, B. C., (2006), "Retirement villages: An alternative form of housing on an ageing landscape", Retrieved from https://www.msd.govt.nz/about-msd-and-our-work/publi cations-resources/journals-and-magazines/social-policy-journal/spj27/retirementvillages-alternative-form-housing-27-pages 100-113.html

Grønhaug, K., Kleppe, I. A., \& Haukedal, W., (1987), Observation of a strategic household purchase decision, Psychology \& Marketing, vol. 4, no. 3, pp. 239-253.

Ha, H. Y., \& Janda, S., (2012), Predicting consumer intentions to purchase energy-efficient products, Journal of Consumer Marketing, vol. 29, no. 7, pp. 461-469.

Hair, J. F., Hult, G. T. M., Ringle, C., \& Sarstedt, M., (2016), A primer on partial least squares structural equation modeling (PLS-SEM), Sage Publications.

Hair, J. F., Sarstedt, M., Ringle, C. M., \& Gudergan, S. P., (2017), Advanced issues in partial least squares structural equation modeling, Sage Publications.

Hanisch, K. A., (1995), Behavioral families and multiple causes: Matching the complexity of responses to the complexity of antecedents, Current Directions in Psychological Science, vol. 4, no. 5, pp. 156-162.

Hassan, A., Cheen, K., \& Rahmawaty., (2011), Sustainable housing practices in Malaysian housing development: Towards establishing a sustainability index, International Journal of Technology, vol. 1, pp. 84-93.

Hu, X., Xia, B., Skitmore, M., \& Buys, L., (2015), Conceptualizing sustainable retirement villages in Australia, Thirty-First Annual Conference 2015 September 7-9, p. 357. 
Hu, X., Xia, B., Skitmore, M., Buys, L., \& Hu, Y., (2017), What is a sustainable retirement village? Perceptions of Australian developers, Journal of Cleaner Production, vol. 164, pp. 179-186

Hulland, J., (1999), Use of partial least squares (PLS) in strategic management research: A review of four recent studies, Strategic Management Journal, pp. 195-204.

Iwarsson, S., (2005), A long-term perspective on person-environment fit and ADL dependence among older Swedish adults, The Gerontologist, vol. 45, no. 3, pp. 327336.

Joo, S. H., \& Pauwels, V., (2002), Factors affecting workers' retirement confidence: A gender perspective, Journal of Financial Counseling and Planning, vol. 13, no. 2, pp. 1-10.

Judd, B., Olsberg, D., Quinn, J., Groenhart, L., \& Demirbilek, O., (2010), Dwelling, land and neighbourhood use by older home owners, Australian Housing and Urban Research Institute.

Kataria, A., Mukherjee, J., Biswas, S., \& Garg, R., (2016), An exploration of consumers' perceived value of sustainable brands in India, Asian Journal of Business Research, vol. 6 , no. 2.

Kennedy, D. J., \& Coates, D., (2008), Retirement village resident satisfaction in Australia: A qualitative enquiry, Journal of Housing for the Elderly, vol. 22, no. 4, pp. 311-334.

Kerr, J., Rosenberg, D., \& Frank, L., (2012), The role of the built environment in healthy aging: community design, physical activity, and health among older adults, Journal of Planning Literature, vol. 27, no. 1, pp. 43-60.

Kim, D. J., Ferrin, D. L., \& Rao, H. R., (2008), A trust-based consumer decision-making model in electronic commerce: The role of trust, perceived risk, and their antecedents, Decision Support Systems, vol. 44, no. 2, pp. 544-564.

Kimiyaghalam, F., Mansori, S., Safari, M., \& Yap, S., (2017), Parents' Influence on Retirement Planning in Malaysia, Family and Consumer Sciences Research Journal, vol. 45, no. 3, pp. 315-325.

King, N., (2003), Continuing care retirement communities: description and an evaluation, Housing, Care and Support, vol. 6, no. 4, pp. 29-33.

Kline, R. B., (2011), Convergence of structural equation modeling and multilevel modeling, Sage Publications.

Korkmaz, S., Riley, D., \& Horman, M., (2010), Piloting evaluation metrics for sustainable high-performance building project delivery, Journal of Construction Engineering and Management, vol. 136, no. 8, pp. 877-885.

KPMG, (2009), "Monash baby boomer study", Retrieved from http://bernardsalt.com.au/uplo ads/09Monash-BabyBoomerStudy-BS0312-MAR.pdf

Laforet, S., \& Saunders, J., (2007), How brand portfolios have changed: A study of grocery suppliers brands from 1994 to 2004, Journal of Marketing Management, vol. 23, no. 1-2, pp. 39-58.

Lai, M. M., Lai, M. L., \& Lau, S. H., (2009), Managing money and retirement planning: Academics' perspectives, Pensions: An International Journal, vol. 14, no. 4, pp. 282292.

Lawton, M. P., (1977), An ecological theory of aging applied to elderly housing, Environment and Aging, vol. 31, no. 1, pp. 8-10.

Lawton, M. P., (1990), Knowledge resources and gaps in housing for the aged, Aging in Place, pp. 287-309.

Li, L., \& Buhalis, D., (2006), E-Commerce in China: The case of travel, International Journal of Information Management, vol. 26, no. 2, pp. 153-166.

Lutz, R. J., \& Reilly, P. J., (1974), An exploration of the effects of perceived social and performance risk on consumer information acquisition, Association for Consumer Research, pp. 393-405.

MacFarland, D. M., Marconi, C. D., \& Utkus, S. P., (2004), Money attitudes and retirement plan design: One size does not fit all, Retrieved from http://www.oxfordscholarshi p.com/view/10.1093/0199273391.001.0001/acprof-9780199273393-chapter-6 
Moen, P., Sweet, S. \& Swisher, R., (2005), Embedded career clocks: The case of retirement planning, Advance in Life Course Research, vol. 9, pp. 237-265.

Morrisonn, A. M., Jing, S., O'Leary, J. T., \& Cai, L. A., (2001), Predicting usage of the Internet for travel bookings: An exploratory study, Information Technology \& Tourism, vol. 4, no. 1, pp. 15-30.

Ng, T. H., Tay, W. Y., Tan, N. L. \& Lim, Y. S., (2011), Influence of investment experience and demographic factors on retirement planning intention, International Journal of Business and Management, vol. 6, no. 2, pp.196-203.

Noone, J. H., Stephens, C., \& Alpass, F., (2010), The process of retirement planning scale (preps): Development and validation, Psychological Assessment, vol. 22, pp. 520531.

Papargyropoulou, E., Padfield, R., Harrison, O., \& Preece, C., (2012), The rise of sustainability services for the built environment in Malaysia, Sustainable Cities and Society, vol. 5, pp. 44-51.

Parment, A., (2013), Generation Y vs. Baby Boomers: Shopping behavior, buyer involvement and implications for retailing, Journal of Retailing and Consumer Services, vol. 20, no. 2, pp. 189-199.

Petkoska, J., \& Earl, J. K., (2009), Understanding the influence of demographic and psychological variables on retirement planning, Psychology and Aging, vol. 24, no. 1, pp. 245.

Podsakoff, P. M., MacKenzie, S. B., Lee, J. Y., \& Podsakoff, N. P., (2003), Common method biases in behavioral research: a critical review of the literature and recommended remedies, Journal of Applied Psychology, vol. 88, no. 5, pp. 879.

Poterba, J., Venti, S., \& Wise, D., (2011), The composition and drawdown of wealth in retirement, Journal of Economic Perspectives, vol. 25, no. 4, pp. 95-118.

Quine, S. \& Carter, S., (2006), Australian baby boomers' expectations and plans for their old age, Australian Journal on Ageing, vol. 25, no. 1, pp. 3-7.

Richardson, V., \& Kilty, K. M., (1989), Retirement financial planning among black professionals, The Gerontologist, vol. 29, no. 1, pp. 32-37.

Rotolo, T., \& Wilson, J., (2004), What happened to the "long civic generation"? Explaining cohort differences in volunteerism, Social Forces, vol. 82, no. 3, pp. 1091-1121.

Sarstedt, M., Wilczynski, P., \& Melewar, T. C., (2013), Measuring reputation in global markets-A comparison of reputation measures' convergent and criterion validities, Journal of World Business, vol. 48, no. 3, pp. 329-339.

Schewe, C. D., \& Noble, S. M., (2000), Market segmentation by cohorts: The value and validity of cohorts in America and abroad, Journal of Marketing Management, vol. 16, no. $1-3$, pp. 129-142.

Schiffman, L. G., \& Kanuk, L. L., (2004), Consumer behaviour, Upper Saddle.

Shah, R., \& Goldstein, S. M., (2006), Use of structural equation modeling in operations management research: Looking back and forward, Journal of Operations Management, vol. 24, no. 2, pp. 148-169.

Shook, C. L., Ketchen, D. J., Hult, G. T. M., \& Kacmar, K. M., (2004), An assessment of the use of structural equation modeling in strategic management research, Strategic Management Journal, vol. 25, no. 4, pp. 397-404.

Simpson, M., \& Cheney, G., (2007), Marketization, participation, and communication within New Zealand retirement villages: A critical-rhetorical and discursive analysis, Discourse \& Communication, vol. 1, no. 2, pp. 191-222.

Stimson, R. J., (2002), The retirement village industry in Australia: evolution, prospects, challenges, The University of Queensland Press.

Stimson, R. J., \& McCrea, R., (2004), A push-pull framework for modelling the relocation of retirees to a retirement village: The Australian experience, Environment and Planning, vol. 36, no. 8, pp. 1451-1470.

Stimson, R. J., McGovern, S., \& Earl, G. W. G., (2002), An ageing population and housing choices for retirees. 
Sweeney, J. C., Soutar, G. N., \& Johnson, L. W., (1999), The role of perceived risk in the quality-value relationship: a study in a retail environment, Journal of Retailing, vol. 75, no. 1, pp. 77-105.

Taylor, A., Pilkington, R., Feist, H., Dal Grande, E., \& Hugo, G., (2014), A survey of retirement intentions of baby boomers: An overview of health, social and economic determinants, BMC Public Health, vol. 14, pp. 355-364.

Taylor, J. W., (1974), The role of risk in consumer behavior, The Journal of Marketing, pp. 54-60.

The Star Online, (2017), "Senior citizens prefer to 'age in place", Retrieved from http://www.thestar.com.my/news/nation/2017/07/09/senior-citizens-prefer-to-age-inplace/

Thorelli, H. B., Lim, J. S., \& Ye, J., (1989), Relative importance of country of origin, warranty, and retail store image on product evaluations, International Marketing Review, vol. 6, no. 1 .

Ting, H., \& de Run, E.C., (2015), A qualitative inquiry into the formation of generational cohorts: A case of an emerging market, Journal of Economics and Business Research, vol. 21, no. 1, pp.126-143.

Ting, H., Lim, T. Y., de Run, E. C., Koh, H., \& Sahdan, M., (2018), Are we Baby Boomers, Gen $\mathrm{X}$ and Gen Y? A qualitative inquiry into generation cohorts in Malaysia, Kasetsart Journal of Social Sciences, vol. 39, no.1, pp.109-115.

Tinker, A., Ginn, J. and Ribe, E., (2013), "Assisted living platform: The long term care revolution: A study of innovatory models to support older people with disabilities in the Netherlands", Retrieved from https://www.ifa-fiv.org/publication/health/assistedliving-platform-the-long-term-care-revolution-a-study-of-innovatory-models-tosupport-older-people-with-disabilities-in-the-netherlands/

Van Rooij, M. C., Lusardi, A., \& Alessie, R. J., (2011), Financial literacy and retirement planning in the Netherlands, Journal of Economic Psychology, vol. 32, no. 4, pp. 593608.

Vermeulen, I. E., \& Seegers, D., (2009), Tried and tested: The impact of online hotel reviews on consumer consideration, Tourism Management, vol. 30, no. 1, pp. 123-127.

Walker, E., \& McNamara, B., (2013), Relocating to retirement living: An occupational perspective on successful transitions, Australian Occupational Therapy Journal, vol. 60 , no. 6, pp. 445-453.

West, S., (2001), Improving the sustainable development of building stock by the implementation of energy efficient, climate control technologies, Building and Environment, vol. 36, no. 3, pp. 281-289.

Xia, B., Zuo, J., Skitmore, M., Chen, Q. \& Rarasati, A. D., (2015), Sustainable retirement village for older people: A case study in Brisbane, Australia, International Journal of Strategic Property Management, vol. 19, no. 2, pp. 149-158.

Zhang, H., Lu, Y., Gupta, S., \& Zhao, L., (2014), What motivates customers to participate in social commerce? The impact of technological environments and virtual customer experiences, Information \& Management, vol. 51, no. 8, pp. 1017-1030.

Zuo, J., Xia, B., Barker, J., \& Skitmore, M., (2014), Green buildings for greying people: A case study of a retirement village in Australia, Facilities, vol. 32, no. 7-8, pp. 365. 